Whether any of the above proteins wholly lack the tryptophane group could not be determined, as we were able to get a very slight reaction with a relatively large quantity of zein by cautiously adding the sulphuric acid up to one-half the volume of the glyoxylic acid. The color thus produced was, at the most, very slight and transitory. With the alcohol-soluble proteins of the oat and barley malt, the brown color was sufficient to obscure a slight violet reaction, and the result of the test in these cases was not conclusive.

It is interesting to note the very marked difference in the intensity of the reaction with the proteins at the two ends of the table and it is fair to presume that the proportion of tryptophane yielded by the several proteins differs considerably.

[CONTRIBUTIONS FROM THE BUREAU OF CHEMISTRY, DEPARTMENT OF AGRICUITURE, No. 49.]

DISAPPEARANCE OF REDUCING SUGAR IN SUGAR-CANE.

BY H. W. WILEY.

Receiveri June Ir, 3903.

THE occurrence of reducing sugar in sugar canes and sorghums has important relations to the metabolism of the plants. Presumably the carbohydrate which is finally formed in the chlorophyl cells of these plants is some variety of starch, probably a soluble variety, since starch granules, as such, would find obstructions to circulation in the return currents from the leaves to the body of the plant. During the early stages of growth it has been shown by repeated analyses that the proportion of reducing sugar to sucrose in the juices of the sugar cane is very high. In Louisiana, where the canes are harvested necessarily before growth is complete, the average quantity of reducing sugars in the juice is I per cent. or more. In the tropics at the time of harvest the percentage of reducing sugars is very much less, usually less than 0.5 per cent. These facts show beyond doubt that the highest relative value of reducing sugar to sucrose is in the earlier stages of growth and the lowest proportion in the matured stages. Theoretically, then, we might expect that at a certain period representing the complete and perfect maturity of the plant the reducing sugar would disappear. The further 
phenomenon, however, has also been observed, namely, that when the reducing sugar has been reduced to a minimum on approaching maturity, any deterioration in the plant, due to long standing, overripeness, injury (from frosts or otherwise), tends to reverse the order observed during the growing period, and to increase the percentage of the reducing sugar at the expense of the sucrose. This reversibility of enzymic action has been well established in the case of carbohydrates. ${ }^{1}$ If the sugar cane, therefore, be allowed to normally grow and mature, there is a certain time in its history, as above mentioned, where the proportion of reducing sugar is at a minimum. The theory above outlined receives confirmation in some analytical data secured in this bureau recently on samples of sugar cane grown in Florida. Four samples were obtained which were all harvested at the same time, namely, the middle of May, Igo3. The canes were grown by $\mathrm{W} . \mathrm{H}$. Abel, on Terra Ceia Island, Manatee County, Florida, about I 50 yards from salt water. The soil is sandy to a depth of from i 2 to 18 inches, with a thin stratum of chocolate-colored subsoil resting on clay, which carries some pebble phosphate. The particular samples under question were grown on the cdge of a field next to timber, and being in the outside row, did not get much cultivation and practically no fertilizer. The samples were cut seventeen months from time of planting. The analytical data obtained from the four samples are as follows:

Composition of the JUtce.

$\begin{array}{cccc}\text { Density. } & \text { Sucrose. } & & \\ \text { Per cent. } & \text { Per cent. } & \text { Purity. } & \text { Glucose. } \\ 21.0 & 19.0 & 90.5 & \text { None } \\ 20.8 & 18.7 & 90.0 & \text { None } \\ 20.4 & 18.0 & 88.2 & \text { None } \\ 21.7 & \text { I9.S } & 91.2 & \text { None }\end{array}$

These are the only samples of sugar cane ever analyzed uncler my supervision which did not contain a greater or less quantity of reducing sugar. At the end of two minutes' boiling of the juices with an alkaline copper solution, there was no trace whatever of any reduction. On Icnger continued boiling and after allowing to stand over night, there was a mere trace of reddish precipitate, due doubtless to the inversion of a part of the sucrose. A great many of the canes grown on this field produced tassels, but Mr. Abel did not state in his description whether the four canes sent had

1 Jour. Chem. Soc. Trans., May, 1903, p. 578. 
tasseled or not. The presumption is that they had. We have in the above what appears to be an example of a complete cycle of growth in the sugar cane, probably a cycle which would not be realized farther south. Evidently the cool nights of the winter had helped to complete the period of growth, while at the same time they prevented a beginning of the second growth, which would certainly have reversed the metabolic activities within the cane and secured an inversion of a part of the sucrose. It is probable that the meteorological conditions which produced so complete a growth do not often obtain and the above data are therefore of interest, both from a chemical and physiological point of view. The analyses were made in the Sugar Laboratory by Mr. Arthur Given.

\section{COLORING-MATTER IN YELLOWISH GRAY SUGAR.}

BY Y. NIKaIDO.

Received June 27. 1903 .

THE crystallized sugar we obtained from the last few straight pans in the I902 campaign, at the sugar factory.operated by the Standard Beet Sugar Co., Leavitt, Neb., acquired a slight yellowish gray tint. The samples were saved and subjected to investigation. Since we could not rake a series of investigations at this time of the year, the work is not complete, but some of the statements may be interesting to sugar-makers.

Herzfeld considers iron oxide as one of the causes of the gray coloration of crystailized sugar. ${ }^{1}$ For this reason, the sample of sugar in question was tested qualitatively. Iron oxide, lime, soda and potash salts and a little organic coloring-matter were found in it. In order to ascertain how much iron oxide in the massecuite is sufficient to produce a yellowish tint in the sugar crystals, the quantity of the iron oxide in the massecuite sample was estimated and found to be 0.02 per cent. As it seemed doubtful that such a small amount of iron oxide in the massecuite would cause the coloration of sugar crystals, complete analyses of the massecuite and ash of the same were made and the results obtained were as follows:

I Ztschr. Rubenzuckerind., 46, I (1896). 